\title{
Correction to: Diabetes Technol Ther 2019;21(2):66-72
}

In the original article, "State of Type 1 Diabetes Management and Outcomes from the T1D Exchange in 2016-2018" by Nicole C. Foster, et al., Volume 21, no. 2, 2019, pp 66-72, an unintentional typographical error was recently brought to our attention regarding the reporting of frequency of adults meeting ADA HbAlc goals.

On page 70, under Metabolic control - 2016-2018, the statement should read: “The American Diabetes Association (ADA) $\mathrm{HbAlc}$ target as of 2018 of $<7.5 \%$ ( $<58 \mathrm{mmol} / \mathrm{mol})$ for youth with T1D was achieved by only a small percentage of children and adolescents $<18$ years old $(17 \%)$; only $21 \%$ of adults achieved the ADA goal of $<7.0 \%(<53 \mathrm{mmol} / \mathrm{mol})$ and $37 \%$ of adults had $\mathrm{HbA} 1 \mathrm{c}$ values of $<7.5 \%$ ( $<58 \mathrm{mmol} / \mathrm{mol})$.'

The online version will be revised to reflect the statement above.

The authors regret the error. 